\title{
APPLICATION OF THE LAPLACE TRANSFORM FOR THE EVALUATION OF CONSOLS' PRESENT VALUE
}

\author{
Jiř́í Mazurek
}

\section{Klíčová slova:}

budoucí hodnota, Laplaceova transformace, perpetuitní dluhopis, současná hodnota, tok výnosů

\section{Keywords:}

consol, future value, Laplace transform, present value, stream of returns

\begin{abstract}
Abstrakt
Cílem článku je demonstrovat užití Laplaceovy transformace k určení současné hodnoty perpetuitních dluhopisů (perpetuit) při různém toku výnosů (dividend). Perpetuity jsou dluhopisy bez data splatnosti, což znamená, že dividenda je placena držiteli dluhopisu (většinou ročně) do nekonečna. Současná hodnota perpetuity při konstantní dividendě je rovna podílu této dividendy a diskontní míry. Když se však dividenda mění v čase, je výpočet současné hodnoty perpetuity složitější. V první části článku je ukázáno, že Laplaceovu transformaci toku výnosů lze využít k výpočtu současné hodnoty perpetuity při spojitém úrokování, a užitím inverzní Laplaceovy transformace je dále možné zrekonstruovat neznámý tok výnosů ze známé současné hodnoty perpetuity. Ve druhé části článku je užití Laplaceovy transformace ilustrováno na několika př́kladech.
\end{abstract}

\begin{abstract}
The aim of the article is to demonstrate the use of the Laplace transform to the evaluation of consols' present value under different streams of returns (dividends). Consols (or perpetual bonds, perpetuities) are bonds with no maturity, which means that interest is paid to a bondholder perpetually (usually annually) forever. The present value of a consol, when constant interest is paid, is simply a ratio of this interest and interest rate. However, when interest payments (stream of returns to a bondholder) change in time the evaluation of consol's present value is more complicated. In the first part of this article it is shown that the Laplace transform of a stream of returns can be used to the evaluation present value of a consol under assumption of continuous compounding; and moreover, with the inverse Laplace transform an unknown stream of returns can be reconstructed from the known consol's present value. In the second part of the paper, the use of the Laplace transform for the present value evaluation is illustrated by examples.
\end{abstract}

\section{Introduction}

The Laplace transform, named after French mathematician and astronomer Pierre-Simon Laplace (1749-1827), is the integral transformation widely used in many areas of physics and engineering. It belongs into broader class of integral transformations including Fourier, Hartley, Hilbert, Poisson, Weierstrass and other transforms. The main area of the application of the Laplace transform is the solution of ordinary and partial differential equations (see e.g. [3], [8], [9] or [10]), because the Laplace transform converts differential equations into algebraic ones, which are easier to handle with. Another area of application includes signal and image processing, the theory of electric circuits, probability theory or impuls-response analysis. In economics, the Laplace transform can be applied to the analysis of dynamics and shocks in time series of macroeconomic indicators [4], for pricing barrier options [7], analysis 
of continuous-time stochastic processes such as Brownian motion [6] or to the evaluation of the present value of consols (see [2] or [5]).

This article focuses on the last issue. Consols (or perpetual bonds, perpetuities) are bonds with no maturity, which means that an interest is paid to a bondholder perpetually (usually annually) forever. The name comes from British government bonds originally issued in 1751 after years of wars to consolidate British economy. Occasionally, other governments issue consols too, such as Canadian government in the late 1970s. The value of a consol is equal to the ratio of interest and interest rate. Therefore, consol's value rises when interest rates decreases and vice versa. However, this formula holds only when interest is constant in time. The Laplace transform provides an easy way to the evaluation of consol's present value under different streams of returns (when interest changes), as well as it provides a solution to the inverse problem: finding an unknown stream of returns when a bond's present value is known. Therefore, the aim of the article is to demonstrate the use of the Laplace transform to the evaluation of consol's present value.

The article is organized as follows: in Section 2 the Laplace transform and its basic properties are introduced, in Section 3 the present and the future value of payments is briefly described and Section 4 provides the evaluation of the present value of consols as well a solution to the inverse problem with unknown streams of return.

\section{The Laplace transform}

Definition 1. Let $f(t)$ be a piece-wise continuous function and let $K(t, p)$ be a continuous function of two variables called a kernel. The integral transform $T$ of $f(t)$ is defined as:

$$
T(p)=\int_{a}^{b} f(t) K(p, t) d t
$$

According to Definition 1, the integral transform assigns a function $f(t)$ a unique function $T(p)$. The function $f(t)$ is the original, the function $T(p)$ is the image. Different kernels $K(t, p)$ yield different integral transforms. For $K(p, t)=e^{-p t}, a=0$ and $b=+\infty$ in Definition 1 the Laplace transform is obtained:

Definition 2. Let $f(t)$ be a piece-wise continuous function of time $t, t \geq 0$, and let $p \in C$. Then the Laplace transform of a function $f(t)$ is defined as:

$$
L[f(t)](p)=\int_{0}^{+\infty} f(t) e^{-p t} d t
$$

The improper integral on the right hand side of (2) absolutely converges for any time function $f(t)$ such that $|f(t)| \leq M e^{\alpha t}$ for $t \geq 0, M>0$ and $a>\alpha$, see [8].

Theorem 1. Functions $L(p)$ and $f(t)$ from Definition 2 are related uniquely by relation (2). Proof: see e.g. [9] or [10].

Theorem 2. Laplace transform is linear: $L[a f(t)+b g(t)]=a L[f(t)]+b L[g(t)]$ Proof: the theorem follows directly from the integral definition.

The Laplace transform of the most widely used functions is shown in Table 1. The use of these formulas is demonstrated in Section 4. Another important properties of the Laplace transform, such as the inverse Laplace transform (the Bromwich integral) or Borel's 
convolution theorem are omitted here as they are not necessary for the explanation, but they can be found in [3], [8], [9] or [10].

\begin{tabular}{|c|c|}
\hline Original $f(t)$ & Image $\mathrm{L}(p)$ \\
\hline 1 & $\frac{1}{p}$ \\
\hline$t^{n}$ & $\frac{n !}{p^{n+1}}$ \\
\hline $\mathrm{e}^{a t}$ & $\frac{1}{p-a}$ \\
\hline$t^{n} \cdot e^{a t}$ & $\frac{n !}{(p-a)^{n+1}}$ \\
\hline $\sin \omega t$ & $\frac{\omega}{p^{2}+\omega^{2}}$ \\
\hline $\cos \omega t$ & $\frac{p}{p^{2}+\omega^{2}}$ \\
\hline$e^{a t} \sin \omega t$ & $\frac{\omega}{(p-a)^{2}+\omega^{2}}$ \\
\hline$e^{a t} \cos \omega t$ & $\frac{p}{(p-a)^{2}+\omega^{2}}$ \\
\hline Dirac's $\delta$-function & 1 \\
\hline
\end{tabular}

Table 1. The Laplace transforms of selected functions ( $a, \omega \in R, n \in N_{0}$ ).

\section{The present and the future value}

The future value (FV) of the present value (PV) of a payment after $n$ periods of time (usually years) with the effective interest rate $r$ is given as:

$$
F V=P V(1+r)^{n}
$$

For the present value of a payment we obtain:

$$
P V=F V(1+r)^{-n} \text {. }
$$

The future value of the present value with periodic compounding of interest, where $n$ is the number of times interest is compounded per year and $t$ denotes the number of years, is given as:

$$
F V=P V\left(1+\frac{r}{n}\right)^{n t}
$$

And for the present value we obtain:

$$
P V=F V\left(1+\frac{r}{n}\right)^{-n t}
$$


Suppose that compounding is continuous $(n \rightarrow \infty)$. With the use of well-known limit for the Euler's number: $\lim _{n \rightarrow \infty}\left(1+\frac{r}{n}\right)^{n}=e^{r}$, see [1], we transform (5) and (6) into the following formulas for the future value and the present value respectively:

$$
\begin{aligned}
& F V=P V \cdot e^{r t}, \\
& P V=F V \cdot e^{-r t} .
\end{aligned}
$$

Now, let's consider a stream of returns (or payments) instead of a single return. This situation might be relevant for large companies with continuous returns such as chain stores, electricity providers, Internet commerce and others. To achieve the present value of a stream of returns $S(t)$ over a period of $M$ years, we divide the interval $[0, M]$ into $n$ subintervals such that: $0=t_{0}<t_{1}<t_{2}<\ldots<t_{n}=M$. We assume that in each interval $\left[t_{i-1}, t_{i}\right]$ of a length $\Delta t_{i}=t_{i}-t_{i-1}$ a single return $S(i)$ is realized. Then the future and the present value of the stream of returns $S\left(t_{i}\right)$ with the interest $r$ are given as:

$$
\begin{gathered}
F V=\sum_{i=1}^{n} S\left(t_{i}\right) \cdot e^{r t_{i}} \cdot \Delta t_{i}, \\
P V=\sum_{i=1}^{n} S\left(t_{i}\right) \cdot e^{-r t_{i}} \cdot \Delta t_{i} .
\end{gathered}
$$

Making intervals $\left[t_{i-1}, t_{i}\right]$ in (9) and (10) infinitesimally small $(n \rightarrow \infty)$ yields the following integral formulas:

$$
\begin{aligned}
& F V=\int_{0}^{M} S(t) \cdot e^{r t} d t, \\
& P V=\int_{0}^{M} S(t) \cdot e^{-r t} d t .
\end{aligned}
$$

In the case of consols a peridic interest is paid virtually forever, so the value $M$ is infinite $(M \rightarrow \infty)$ and from (11) and (12) we obtain:

$$
\begin{aligned}
& F V=\int_{0}^{\infty} S(t) \cdot e^{r t} d t, \\
& P V=\int_{0}^{\infty} S(t) \cdot e^{-r t} d t .
\end{aligned}
$$

By the comparison of (2) and (14) we see that to obtain the present value of a stream of returns $S(t)$ we have to find the Laplace transform of a function $S(t)$, where $p$ in Definition 2 corresponds to the interest rate $r$. Moreover, it is possible to recover unknown stream of returns from a known present value through the inverse Laplace transform (or we can simply use results provided in Table 1 'backwards'). The use of the Laplace transform for the consols present value evaluation is illustrated in the next Section.

\section{The evaluation of consol's present value by the Laplace transform}

In this Section the use of the Laplace transform for the evaluation of consol's present value with different streams of returns is demonstrated on several examples. 
Example 1. Let the stream of returns $S(t)$ be a constant value $k$ and interest rate be $r$. What is the present value of a consol?

From (14) and Table 1 ( $1^{\text {st }}$ row $)$ we get:

$P V=\int_{0}^{\infty} k \cdot e^{-r t} d t=\frac{k}{r}$

The ratio $\frac{k}{r}$ is a well-known formula for the present value of a consol. For example, if $k=$ $1 \$ /$ per year and $r=2 \%(0.02)$, then $\mathrm{PV}=50 \$$.

Example 2. Let $r$ be interest rate and let the stream of returns $S(t)$ be exponentially growing at a rate $q, q<r$. What is the present value of a consol?

From (14) and Table 1 ( $3^{\text {rd }}$ row) we get:

$P V=\int_{0}^{\infty} e^{q t} \cdot e^{-r t} d t=\frac{1}{r-q}$.

For example, if $q=1 \%$ and $r=2 \%$, then $\mathrm{PV}=100 \$$.

Example 3. Let the stream of returns be linearly growing, $S(t)=t$ with interest rate $r$. What is the present value of a consol?

From (14) and Table 1 ( $2^{\text {nd }}$ row) we get:

$P V=\int_{0}^{\infty} t \cdot e^{-r t} d t=\frac{1}{r^{2}}$.

For example, if $r=3 \%$, then PV $=1111.1 \$$.

Example 4. The present value of a consol with the interest rate $r$ is $\frac{1}{r(r-1)}$, find the stream of returns $S(t)$.

First, we transform a given fraction in two partial fractions: $\frac{1}{r(r-1)}=-\frac{1}{r}+\frac{1}{r-1}$ Then we use Table $1\left(1^{\text {st }}\right.$ and $3^{\text {rd }}$ row $)$ to find the original to these images: $L^{-1}\left(-\frac{1}{r}\right)=-1$ and $L^{-1}\left(\frac{1}{r-1}\right)=e^{t}$. With the use of Theorem 2 (linearity of the Laplace transform) we finally obtain the stream of returns $S(t)=e^{t}-1 \$$ /year. Finally, Theorem 1 ensures this is the only solution to the problem.

Example 5. Use the result of Example 1 to find the stream of returns $S(t)$ for the present value given as the Heaviside function: $f(x)=1$ for $x \geq 0$ and $f(x)=0$ for $x<0$.

If $\mathrm{PV}=1$, then from Example 1 we obtain: $k=r \Rightarrow S(t)=r$. The stream of returns must be constant and equal to the interest rate $r$. 


\section{Conclusion}

The aim of the article is to demonstrate the application of the Laplace transform in economics, namely in the evaluation of consol's present value of consols when different streams of returns (constant, linearly or exponentially growing, etc.) are involved. The Laplace transform allows easy computation of consol's present value from the known stream of returns, but it also enables to reconstruct unknown pattern of returns from the present value through inverse Laplace transformation. In the last section of the paper, the use of the Laplace transform is illustrated on several examples.

\section{Literature:}

[1] ABRAMOWITZ, M., STEGUN, A. I. (eds). Handbook of Mathematical Functions with Formulas, Graphs and Mathematical Tables. New York: Dover Publications, 1972.

[2] BUSER, S. A. Laplace Transform as Present Value Rules: A Note. Journal of Finance, 1986, Vol. 41, No. 1, p.243-247.

[3] DOETSCH, G. Introduction to the Theory and Application of the Laplace Transformation. Berlin: Springer-Verlag, 1974.

[4] GRUBBSTROM, R. W. On the Application of the Laplace Transform to Certain Economic Problems. Management Science, 1967, Vol. 13, No. 7, p 558-567.

[5] HAMILTON, J. Time Series Analysis. Princeton University Press, 1994.

[6] LOCHOWSKI, R. On the Laplace transform on some functionals related to the variation of Brownian motion with drift. International workshop on applied probability (IWAP), Madrid, 2010.

[7] PELSSER, A. Pricing double barrier options using Laplace transforms. Finance and Stochastics, 2000, Vol. 4, No. 1, p. 95-104.

[8] PÍRKO, Z., VEIT, J. Laplaceova transformace. Praha: SNTL, 1972.

[9] SPIEGEL, M. R. Theory and Problems of Laplace Transforms. New York: McGraw-Hill, 1965.

[10] ŠKRÁS̆EK, J., TICHÝ, Z. Základy aplikované matematiky II. Praha: SNTL, 1986.

\section{JEL C65, G12}

\section{Mgr. Jiř́i Mazurek, Ph.D.}

Odborný asistent Katedra matematických metod v ekonomii

Obchodně podnikatelská fakulta v Karviné

Slezská univerzita v Opavě

Univerzitní náměstí 1934/3, 73340 Karviná

mazurek@opf.slu.cz 